\title{
Comparing Student Engagement in Online and Face-to-Face Instruction in Health and Physical Education Teacher Preparation
}

\author{
Frank Butts ${ }^{1}$, Brent Heidorn ${ }^{1} \&$ Brian Mosier ${ }^{1}$ \\ ${ }^{1}$ Department of Leadership and Instruction, University of West Georgia, Carrollton, USA \\ Correspondence: Brent Heidorn, Department of Leadership and Instruction, University of West Georgia, \\ Carrollton, GA, 30118, USA. E-mail: bheidorn@westga.edu
}

Received: January 4, 2013

Accepted: February 25, 2013

Online Published: April 2, 2013

doi:10.5539/jel.v2n2p8

URL: http://dx.doi.org/10.5539/jel.v2n2p8

\begin{abstract}
Purpose: The purpose of this study was to see if there was a significant difference in engagement among undergraduate health and physical education majors when comparing online instruction to traditional lecture format. Method: Participants in this study were 22 undergraduate health and physical education majors enrolled in the summer semester, in a three-hour class. Two sections of the course were offered to the students. One section was delivered online and the other was delivered by traditional lecture in a face-to-face setting. The course curriculum and assignments were identical for the online and face-to-face courses. Analysis: Thirty-four Likert-scaled questions were used to determine student perception of engagement in the course. Difference in responses of the two study groups were examined using the Mann-Whitney Test $(p=.05)$. Results: The results of this study showed no significant difference in 33 of the 34 variables used to measure engagement. Conclusions: It seems clear from this study that students in undergraduate physical education teacher preparation courses can be engaged in course content, whether that content is offered completely online, or in a traditionally-based face-to-face format.
\end{abstract}

Keywords: engagement, undergraduate, physical education

\section{Introduction}

As more students engage in online course work, universities are trying to keep up with the growing demand for Internet-based classes. Student online enrollment increased 17 percent from the previous year, while traditional student enrollment only increased 1.2 percent (Allen \& Seaman, 2010). Universities can meet the growing demand for online learning by focusing on factors that influence students' satisfaction and overall success in online learning. Research examining student overall satisfaction in online learning is extensive. Recent studies addressing online learning and online learner satisfaction have focused on several themes, including student characteristics, student interaction, course design and instruction, student assessment, and technology, though not the delivery mode itself. The following paragraphs provide a brief summary of the current literature for each theme.

\subsection{Student Characteristics}

Student characteristics are common factors examined in evaluating the online learner. Demographics have been examined in numerous studies; however the specific demographics for each study tend to vary. In a recent study (Pontes, Hasit, Pontes, Lewis, and Siefring, 2010), the authors note that students who preferred enrolling in online classes were typically found to be married or living with children in their household, have mobility limiting disabilities, or work in addition to their online learning. In another recent study, other predictors included increased living distance from campus and graduate students as factors for increased online enrollment (Beqiri, Chase, \& Bishka, 2010; Muilenberg \& Zane, 2005; Pontes et al.). Additional documented characteristics influencing online enrollment included: age, family, jobs, and personal schedules (Banks \& Faul, 2007; Bickle \& Carroll, 2003; Clayton, Blumberg, \& Auld, 2010; Muilenberg \& Zane, 2005).

\subsection{Student Interaction}

Student interaction is a focal point when investigating online learning and is closely tied to developing a sense of community. Lao and Gonzales (2005) suggested the development of a learning community as an important attribute to online learning. However, sense of community and connectedness are found to be a challenge to 
students in online learning (Song, Singleton, Hill, \& Koh, 2004; Ritter, Polnick, Fink, \& Oescher, 2010). Lapointe and Reisetter (2008) discovered mixed results pertaining to the value of learning communities. Some students found a positive online community, while others perceived the online community unsupportive in their coursework.

\subsection{Course Design and Instruction}

Research has frequently compared and contrasted student preference for distance learning and traditional face-to-face learning. Song et al. (2004) found that students commonly suggested the design of the course as helpful and challenging in student online success. According to Anderson (2006), students found unorganized instructors to be a negative factor in online learning. Students had overall satisfaction with online learning compared with face-to-face learning when quality of instruction, personal attention of instruction, and rigor of the online curriculum were considered (Hoban, Neu, \& Castel, S., 2002).

\subsection{Student Assessment}

Student assessment and demonstrated knowledge has contributed mixed results to satisfaction in instructional delivery modes including both distance and face-to-face learning. According to Banks and Faul (2007), there was no significant difference in knowledge gained in different instructional delivery modes. Yet research suggests that students have satisfaction in distance education assessments (Sampson, Leonard, \& Coleman, 2010, 2010; Sherman, Crum, , \& Beaty, 2010). According to Pribesh, Dickinson, and Bucher (2006), students scored comparably in distance learning and face-to-face learning; however, students scored less favorably on project-based learning in distance courses compared to face-to-face courses. As evidence of the ambiguity in the literature, Ferguson and Tryjankowski (2009) found that students who were enrolled in face-to-face classes scored better on assessments than students who were enrolled in online classes. However, Tucker (2001) found that students enrolled in distance education scored higher than those in face-to face education in post-test and final exam scores. Further, Sussman and Dutter (2010) provided additional evidence that there was no significant difference in student test scores when online learning and face-to-face learning were compared.

\subsection{Technology}

Student knowledge and perception of technology can shape student satisfaction in online learning (Sahin \& Shelley, 2008). Research suggests computer competency as a barrier to online learning (Muilenburg \& Berge, 2005; Song et al., 2004) because knowledge of basic and specialized programs are necessary for online participation in online courses. Walker and Kelly (2007) found that students considered technology glitches as a significant "pet peeve" in online learning. Students reported difficulties with computer programs, internet sites, and broken links. According to Song et al. (2004), comfort with online technologies was important in learner success. Lao and Gonzales (2005) found that online programs having the right technology and equipment facilitated effective learning and teaching.

\subsection{Distance Education and Student Engagement}

Recent studies of online instruction have tended to focus on the common themes of student satisfaction, characteristics, interactions, course design, instruction and assessment. A new variable gaining attention in the study of online instruction is student engagement. Axelson and Flick (2011) defined engagement as a description of how involved or interested students appear to be in their learning and how connected they are to their classes, institutions and to each other. Axelson and Flick further suggested the need for future research to focus on more practical ways to evaluate engagement in higher education and to understand engagement and its relationship to learning. Chen, Gonyea, and Kuh (2008) found distance learning students equally as engaged as traditional, campus-based learners. Dixson (2010) developed a measure of student engagement in online courses to research what activities and interactions lead to more highly engaged students. This study was conducted in six universities in the Midwest. The relationship between instructor/student presence and student engagement was examined. Dixson found that student-student and instructor-student communication are correlated with higher student engagement in online coursework. Student access to multiple communication channels to increase student engagement was included in this study, but further research is needed to support this notion.

The current study addresses the need to expand future research in the examination of online student engagement. To further study the variable of engagement in online instruction, we expanded the theory posed by Dickson (2010). This study examined two distinct approaches to engagement when teaching undergraduate students in health and physical education at a regional, southern, public university. One approach allowed for both student-student and instructor-student engagement in an online environment and the second approach utilized the traditional, face-to-face lecture format. Therefore, the purpose of this study was to see if there was a significant 
difference in engagement among undergraduate health and physical education majors when comparing online instruction to traditional lecture format.

\section{Method}

\subsection{Participants}

The participants in this study were 22 undergraduate health and physical education majors enrolled in the summer semester, in a three-hour class. The class was titled, "Integrating Technology into Health and Physical Education". Two sections of the course were offered to the students. One section was delivered online and the other was delivered by traditional lecture in a face-to-face setting. The course curriculum and assignments were identical for the online and face-to-face courses. All students had a minimum of a 2.5 grade point average prior to the summer semester. The university is a comprehensive, doctoral granting university accredited by both the SACS and NCATE.

\subsection{Treatment}

The online class $(\mathrm{n}=11)$ was a four-week course comprised of four learning modules. There was one face-to-face meeting at the beginning of the semester and another in the third week. Students had the option to complete all assignments online from a remote location, or use computers on campus. The course was asynchronous in nature and students were expected to complete one module each week. The instructor used written, audio, and video announcements through a learning management system for regular updates. The instructor assessed student assignments through the learning management system and a wiki. Students had the ability to call, text, or email the instructor for assistance.

The face to face class $(\mathrm{n}=11)$ consisted of 11 days of instruction at approximately three hours each day. Students met in the computer lab on campus and proceeded to complete each day's task(s) as directed by the instructor. While some of the lectures consisted of direct instruction, students also learned through other methods (indirect instruction, guided discovery, etc.) either by the instructor or by student-facilitated discussions. The instructor used written and verbal instructions for all tasks that needed to be completed by the students. All completed assignments were submitted to the course wiki site and discussed in class. Students had the ability to call, text, phone, or email the instructor for assistance, in addition to the face to face class meetings.

\section{Analysis}

To measure engagement among students in both groups and to determine if there was a significant difference in the students' feelings of engagement when contrasting face-to-face versus online instruction in physical education, Dixson's (2010) measure of Student Online Engagement was utilized. Thirty-four Likert-scaled questions were used to determine student perception of engagement in the course. Dixson determined that the instrument had a 0.95 reliability coefficient. The data was collected using Survey Monkey, with each student receiving the survey on the final day of the course. The data were analyzed using the Mann-Whitney Test. This non-parametric test was selected as the data collected was ordinal by nature. With the limited population of subjects, it was anticipated that a critical p-value would be difficult to obtain on any of the 34 items analyzed.

\section{Results}

The results of this study, examining the difference in students' perceptions of engagement in face-to-face versus online instruction in physical education teacher preparation classes, showed no significant difference in 33 of the 34 variables used to measure engagement based on the Dixson (2010) measure of Student Online Engagement. Difference in responses of the two study groups were examined using the Mann-Whitney Test $(p=.05)$. The reflection of engagement was significantly better in the online class on one variable as seen in Table 1 . The variable was associated with how well students felt they knew their instructor. In all other factors associated with student engagement, there were no significant differences.

There are two potential limitations to the study. First, the sample size was 11 students in each group. This limited the power of the test and made it harder to find significance. Second, only physical education teacher preparation was considered in the study. It is not known if other teacher preparation programs would experience similar findings. Online courses for other programs may or may not be practical (e.g., laboratory works, industrial training, etc.). 
Table 1. Variables of student engagement in online versus face-to-face physical education classes in undergraduate teacher preparation

\begin{tabular}{|c|c|c|}
\hline Evaluation Item & p-value & significance $(\mathrm{p}<.05)$ \\
\hline Making sure to study on regular basis & 0.0764 & \\
\hline Putting forth effort & 0.194 & \\
\hline Doing all the homework & 0.8811 & \\
\hline Staying up on the readings & 0.158 & \\
\hline Looking over class notes & 0.2625 & \\
\hline Being organized & 0.707 & \\
\hline Taking good notes & 0.8316 & \\
\hline Listening/reading carefully & 0.2276 & \\
\hline Entering the online class multiple times a week & 0.1037 & \\
\hline Making class relevant to my life & 0.8587 & \\
\hline Applying course material to my life & 0.3863 & \\
\hline Finding ways to make the course interesting to me & 0.4895 & \\
\hline Thinking about the course between times I am online & 0.3928 & \\
\hline Desire to learn material & 0.8367 & \\
\hline Visiting or calling the instructor with questions & 0.5627 & \\
\hline Emailing or posting questions when I don't understand & 0.436 & \\
\hline Having fun in online chats, email or other students & 0.7313 & \\
\hline Participating actively in small groups & 0.8125 & \\
\hline Helping fellow students & 0.4621 & \\
\hline Getting a good grade & 0.6843 & \\
\hline Doing well on the tests/quizzes & 0.4245 & \\
\hline Being confident that I can learn & 0.9107 & \\
\hline Taking advantage of all class resources & 0.5129 & \\
\hline Engaging in conversations online & 0.7839 & \\
\hline Critically thinking about ethics, priorities, and values & 0.5642 & \\
\hline Posting in the discussion forum regularly & 0.9453 & \\
\hline Emailing the instructor regarding my grade in the class & 0.2946 & \\
\hline Checking my grades online & 0.5751 & \\
\hline Getting to know other students & 0.5218 & \\
\hline Assessing my own learning and progress & 0.7636 & \\
\hline How engaged are you in this course & 0.9388 & \\
\hline Engaged are you in this course compared to other courses & 0.5647 & \\
\hline How well have gotten to know other students & 0.753 & \\
\hline How well do you feel you know your instructor? & 0.0211 & significant \\
\hline
\end{tabular}

Note. $\mathrm{N}$ group $1=11, \mathrm{~N}$ group $2=11, \mathrm{p}<.05$.

Mann-Whitney test for significance

The Dixson (2010) measure of Student online Engagement, reliability 0.95 was used in this study. 


\section{Discussion}

The emphasis for public and/or private universities to pursue online classes is evident. Recent trends indicate the benefits of offering courses online for a variety of reasons. Based on this information, colleges and universities should continue offering and seeking options of ways to offer online courses for students, without neglecting student learning, engagement, and other valuable outcomes. However, a few key concepts, based on the results of this study need to be addressed.

First, when conducting physical education teacher preparation programs, it is likely that not all courses within the program can or should be offered in a completely online format. The same may also be true with other more traditionally-based teacher preparation programs (i.e., music education, etc.). Therefore, program faculty must first engage in discussions pertaining to which courses within the program are most suitable for online instruction.

Second, although one item demonstrated statistical significance ("how well do you feel you know your instructor"), when looking at it in depth, the authors note that the rating from students in the completely online course was a " 5 " (on a 1 to 5 scale with 5 being the highest), and the rating from students in the face-to-face course was a " 4 ". This information demonstrates very good scores for both sections. Therefore, it seems from the results of this study that both delivery methods have the potential to engage students on "getting to know the instructor".

Considering the above notion, it is possible that students in the completely online course only get an illusion of their teacher, compared to the visible presence of the teacher in the face-to-face course, even though it is recognized that online instruction is indeed a student-centered educational method (as compared to the traditional "teacher-centered method" of face-to-face instruction). Future research could explore the role the teacher plays in the online versus face-to-face methods of instruction, including the level of satisfaction and/or desire to use online instruction, as well as the efforts and time teachers do or should spend on each student in online instruction (compared to face-to-face instruction).

Third and perhaps most revealing, this study demonstrated no significant differences in student perceptions of engagement in an online versus face-to-face undergraduate physical education teacher preparation. Similar results are found in other studies (Ware, 2005). Therefore, it seems clear that students in undergraduate teacher preparation courses can be engaged in course content, whether that content is offered completely online, or in a traditionally-based face-to-face format.

Finally, the authors of this study recognize that online learning is not a "one-size fits all delivery process". When designed and implemented appropriately, undergraduate online education can serve as an appropriate method of instruction. It may match the learning style that prefers independent, self-paced curriculum and provides greater flexibility to students.

\section{References}

Axelson, R. D., \& Flick, A. (2011). Defining student engagement. Change: The Magazine of Higher Learning, 43(1), 38-43. http://dx.doi.org/10.1080/00091383.2011.533096

Artino, A. R. (2010). Online or face-to-face learning? Exploring the personal factors that predict students' choice of instructional format. Internet and Higher Education, 13(4), 272-276. http://dx.doi.org/10.1016/j.iheduc.2010.07.005

Allen, I. E., \& Seaman, J. (2010). Learning on Demand, Online Education in the United States. Needham MA: The Sloan Consortium.

Banks, A. C., \& Faul, A. C. (2007). Reduction of face-to-face contact hours in foundation research courses: Impact on students' knowledge gained and course satisfaction. Social Work Education, 26(8), 780-793. http://dx.doi.org/10.1080/02615470601140500

Beqiri, M. S., Chase, N. M., \& Bishka, A. (2010). Online course delivery: An empirical investigation of factors affecting student satisfaction. Journal of Education for Business, 85(2), 95-100. http://dx.doi.org/10.1080/08832320903258527

Bickle, M. C., \& Carroll, J. C. (2003). Checklist for quality online instruction: Outcomes for learners, the professor, and the institution. College Student Journal, 37(2), 208-216.

Chen, P. S. D., Gonyea, R., \& Kuh, G. (2008). Learning at a distance. Journal of Online Education, 4(3).

Clayton, K., Blumberg, F., \& Auld, D. P. (2010). The relationship between motivation, learning strategies, and 
choice of environment whether traditional or including an online component. British Journal of Educational Technology, 41(3), 349-364. http://dx.doi.org/10.1111/j.1467-8535.2009.00993.x

Dixson, M. D. (2010). Creating effective student engagement in online courses: What do students find engaging? Journal of the Scholarship of Teaching and Learning, 10(2), 1-13.

Ferguson, J., \& Tryjankowski, A. M. (2009). Online versus face-to-face learning: Looking at modes of instruction in master's-level courses. Journal of Further and Higher Education, 33(3), 219-228. http://dx.doi.org/10.1080/03098770903026149

Hoban, G., Neu, B., \& Castel, S. (2002). Assessment of student learning in an educational administration online program.

Lao, T., \& Gonzales, C. (2005). Understand online learning through a qualitative description of professors and student's experiences. Journal of Technology and Teacher Education, 13(3), 459-474.

Lapointe, L., \& Reisetter, M. (2008). Belonging online: Students' perceptions of the value and efficacy of an online learning community. International Journal of ELearning, 7(4), 641-665.

Muilenburg, L. Y., \& Berge, Z. L. (2005). Student barriers to online learning: A factor analytic study. Distance Education, 26(1), 49-48. http://dx.doi.org/10.1080/01587910500081269

Pontes, M. C. F., Hasit, C., Pontes, N. M. H., Lewis, P. A., \& Siefring, K. T. (2010). Variables related to undergraduate students preference for distance education classes. Online Journal of Distance Learning Administration, $\quad 8(2) . \quad$ Retrieved from http://www.westga.edu/ distance/ojdla/summer132/pontes_pontes132.html

Pribesh, S., Dickinson, G. K., Bucher, K. T. (2006). A comparison of online and face-to-face cohorts in a school library media specialist graduate program: A preliminary study. Journal of Education for Library and Information Science, 47(4), 303-323. http://dx.doi.org/10.2307/40323823

Ritter, C., Polnick, B., Fink, R., \& Oescher, J. (2010). Classroom learning communities in educational leadership: A comparison study of three delivery options. Internet and Higher Education, 13(1-2), 96-100. http://dx.doi.org/10.1016/j.iheduc.2009.11.005

Rovai, A. P., \& Jordon, H. M. (2004). Blended learning and sense of community: A comparative analysis with traditional and fully online graduate courses. International Review of Research in Open and Distance Learning, 5(2).

Sahin, I., \& Shelley, M. (2008). Considering students' perceptions: The distance education student satisfaction model. Educational Technology \& Society, 11(3), 216-223.

Sampson, P. M., Leonard, J., Ballenger, J. W., \& Coleman, J. C. (2010). Student satisfaction of online courses for educational leadership. Online Journal of Distance Learning Administration, 8(3). Retrieved from http://www.westga.edu/ distance/ojdla/Fall133/sampson_ballenger133.html

Sherman, W., \& Beaty, D. M. (2007). The use of distance technology in educational leadership preparation programs. Journal of Educational Administration, 45(5), 605-620.

Sherman, W. H., Crum, K. S., \& Beaty, D. M. (2010). Perspectives on distance technology in leadership education: Transfer, meaning, and change. Journal of Research on Leadership Education, 5(13).

Song, L., Singleton, E. S., Hill, J. R., \& Koh, M. H. (2004). Improving online learning: Student perceptions of useful and challenging characteristics. Internet and Higher Education, 7(1), 59-70. http://dx.doi.org/10.1016/j.iheduc.2003.11.003

Sussman, S., \& Dutter, L. (2010). Comparing student learning outcomes in face-to-face and online course delivery. Online Journal of Distance Learning Administration, 8(4). Retrieved from http://www.westga.edu/ distance/ojdla/winter134/sussman_dutter134.html

Tucker, S. (2001). Distance education: Better, worse, or as good as traditional education? Online Journal of $\begin{array}{llll}\text { Distance Learning Administration, 4(4). } & \text { Retrieved from }\end{array}$ http://www.westga.edu/ distance/ojdla/winter44/tucker44.html

Walker, C. E., \& Kelly, E. (2007). Online instruction: Student satisfaction, kudos, and pet peeves. The Quarterly Review of Distance Education, 8(4), 309-319.

Ware, D. M. (2005). Social competence of students enrolled in online high school physical education courses. Unpublished doctoral dissertation, University of Central Florida, Orlando. 